\title{
How Is The Effect Of Labour Absorption, Poverty And Education Level On The Implementation Of Regional Minimum Wage? A case in Riau Province, Indonesia.
}

\author{
Abdiyanto \\ Department of Development Economic Universitas Pembangunan Panca Budi, Medan, \\ North Sumatra, Indonesia \\ *Corresponding Author: Abdiyanto
}

\begin{abstract}
The present study aims to analyze the impact of labour absorption, poverty and education on regional minimum wage implementation in Riau Province. The research is analyzed to find out which variables are most dominant to the minimum wage. The results of the calculation and analysis of dependent and independent variables indicate that the variable of labour absorption, poverty and education level has an effect of $56.87 \%$. The result of labour absorption interpretation is negative value $-0,334$. Other variables were positive values such as poverty of 0.44 and education level of $0.105 \%$ on the implementation of regional minimum wages in Riau Province from 2007-2017.
\end{abstract}

Keywords:- Labour Absorption, Poverty, Education Level, Implementation, Minimum Wages, Regional.

\section{INTRODUCTION}

Labour is a highlight in the discussion of human issues since it is the beginning of the development of the science of economics and social. Furthermore, labour is part of the production factor that will manage and control production, distribution and consumption elements including investment. They want income, security, comfort and humanity. The chain of movement will continue to move and mutual need between human beings and production factors to improve human and economic development.

Improving human development by improving the quality of labour. The low quality of labour is due to the increasing number of labour requires them to be trapped within the unemployment circle. With a growing number of employers requiring a job or company can not absorb, the unemployment rate also increases. The increase is in line with the inability of the labour to meet the basic needs. Labour providers are reluctant to recruit because of educational standards whose labour is low and does not conform to the standards that the company wants.

Many companies are now employing labour that is incompatible with the education they have earned and earns a fee or service that does not fit into the range of labour education. Minimum Wage is the lowest wage reference standard and safety net applied as a minimum wage policy. It also protects the group of workers with low wages comprising wages without allowances and basic wages including fixed allowances. In Government Regulation Number 78 the Year 2015 concerning remuneration as the implementing regulation of Act No. 13 of 2003 on Labour.

The central government specifies the formulation of the minimum wage calculation by the Ministry of Labor to issue a letter containing the National Inflation data and the growth of the National Gross Domestic Product for one year. The letter was addressed to all Governors in Indonesia, then the Governor determined the applicable wage rates at the provincial level, followed by the District and City governments reestablishing new or equal value based on regional minimum wage references approved by the governor and the Regent / Mayor.

The process of determining the minimum wage rates applicable in Indonesia is implemented with a long process. Started District level Regional Wage Board (DPD) containing representatives from bureaucrats/governments, academics, labourers and entrepreneurs to conduct meetings. Then the survey team was set up and scheduled to go down the field to find information on the needs of a full-time Labour at a price. After field surveys at the number of identification points were determined then the Eligible Living Needs.According to Ginnie, the minimum wage policy is a wage system that has been used in Indonesia. As a base can be seen from two sides, First, the minimum wage is a protective tool for workers to maintain the value of wages earned in fulfilling the needs of daily living. Second, as a means of protection against companies or entrepreneurs to maintain production of workers (Simanjuntak, 2002: 1). 
The report notes that Regional Minimum Wage in all regencies/districts in Riau Province has always increased. However, many people still refuse to fix the number, because the nominal amount set by the Regent / Mayor does not have a positive impact on the decline in labour absorption. Companies offering jobs are still hesitant in recruiting new workers in filling up available vacancies. As a result, the number of open unemployment in Riau Province is still increasing. Below is a summary of regional minimum wage issues affecting Labour absorption and regional minimum wages affecting poverty in Riau Province.

\section{The effect of regional minimum wage on labour absorption in Riau Province}

Labour absorption is the acceptance of job seekers to perform the appropriate tasks required by job vacancies or conditions that illustrate the availability of Labour to be filled by job seekers. Based on Law No. 13 of 20013 on Labour explains that labour is a person who can or can carry out activities of producing goods and services to meet the needs of himself and his surroundings. Labour absorption can receive all labour if the business unit or company that offers labour is available and sufficiently meets the amount of available labour. With the ability and expertise of the labour force is expected to meet the labour market offered by the company. In the development of local communities, the population becomes an important pillar in development, as the number of population is increasing every year. It should be utilized and empowered to develop areas that are well advanced with quality human resources.

The number of the labour force in the regencies and districts in Riau Province is still high in population compared to the number of the working population. The number of the labour force has not been absorbed yet, there has been a lack of job opportunities. This problem is absorbed labour that special attention has not been addressed. The higher the number of labour that occupy the job the more jobs it takes. Hence the rapid pace of growth in the labour, the unemployment rate is even greater.

In this regard, the government is required to make policies on how labour increases to impact on the reduction of unemployment in the Riau province. Government policies have a great impact on the welfare of the people in Riau Province. Wages are an important factor affecting the absorption of labour because wages affect the economy on demand and supply of labour. The wage increases will cause the price of goods and services to rise, therefore the worth of living needs that will be more expensive.

\section{The effect of regional minimum wage on poverty in Riau Province}

Poverty is the inability to meet the minimum standard of living that corresponds to the level of living worthy of life. Poverty is a serious problem in the economy, increasing the poverty rate is a threat to the economic growth of the region. Hence poverty becomes a complex and multidimensional problem. And wages are a problem that affects each other in the cycle of poverty. Wages become one measure to know the welfare of labour or household. As an aggregate measure, poverty in a region is used to identify the welfare level of the region (Todaro\& Smith, 2006).Province of Riau is one of the poorest populations in Indonesia. This figure is higher in line with higher population levels. Another factor affecting poverty in a region is unemployment and minimum wage.

\section{The effect of regional minimum wage on education level in Riau Province}

To achieve sustainable development, it is important to improve the quality of life of the labour by influencing the economic system of a country which is classified into two factors namely economic and non-economic factors. Non-economic factors such as education, religion, health and law. Classical groups such as Adam Smith, David Ricardo and Thomas Robert Malthus argued that there is always a reversal between the level of output development and population development. The population as labour will be difficult to provide Labour. If Labour is earned it will increase the welfare of the nation. But if they do not work then they will be unemployed and impact on the standard of living and low wages set (Suparmoko, 2002). Education is the focus of development in improving the standards and quality of human resources, therefore it takes the role of good educators. With the hope of quality education should be balanced educators and high quality (Password, 2013) Here are the data about the percentage of the number of labour who graduated from high school / vocational level to university. 
How is the effect of labour absorption, poverty and education level on the implementation of ....

Table 1 Percentage of Labor Force Completion High School / Vocational Education Until University in Riau Province

\begin{tabular}{|c|c|}
\hline Year & Percentage \\
\hline $\mathbf{2 0 0 7}$ & 34,07 \\
\hline $\mathbf{2 0 0 8}$ & 33,38 \\
\hline $\mathbf{2 0 0 9}$ & 32,07 \\
\hline $\mathbf{2 0 1 0}$ & 32,16 \\
\hline $\mathbf{2 0 1 1}$ & 31,52 \\
\hline $\mathbf{2 0 1 2}$ & 30,26 \\
\hline $\mathbf{2 0 1 3}$ & 29,74 \\
\hline $\mathbf{2 0 1 4}$ & 28,89 \\
\hline $\mathbf{2 0 1 5}$ & 30,35 \\
\hline $\mathbf{2 0 1 6}$ & 20,31 \\
\hline $\mathbf{2 0 1 7}$ & 16,43 \\
\hline
\end{tabular}

Source: Data is processed from Riau BPS, (Sakernas and Susenas as of August 2007 to 2017)

From the above data, it is clear that regional minimum wage causes the absorption rate of the labour who graduated from high school / vocational until university in Riau Province is not well absorbed, as influenced by population density. The average level of education data is $20 \%$ filled by high school-grade labour, they are not absorbed because of the quality and capabilities that are incompatible with the expectations of companies and job seekers.People's education will affect the productivity of their work. Education becomes the capital to increase the productivity that the company expects (Sulistiawati, 2012).

Establishing a minimum wage that does not accommodate all layers will lead to higher poverty. Economically, unemployment affects people's competitiveness and purchasing power directly to society on income levels (Rahmawati, 2016). When low levels of community income will affect purchasing power and low competitiveness, then communities cannot meet the basic needs of food, health and housing, and increase the number of poor people in a region.

These points indicate that the determination affects the absorption of labour and poverty. Such communities are poor because they do not have adequate resources both in natural resources, in human resources and development resources, even if they participate in the development, they are only rewarded with low (Abdiyanto, 2016).Also, human resources or unskilled labour force are not able to fill available jobs. Particularly in a particular field that requires a lot of labour (Basir, 2012).

Therefore, it is important to know the basic reference that can be applied by the regencies and districts government in determining the minimum wage as a basic reference in raising the rate of labour absorption, reducing poverty and recruitment from the education level.

Concerning the above issues, some research questions that highlighted are:

RQ1: How the absorption of labour, poverty and education level partially to the regional minimum wage of regencies \&districts in Riau Province 2007-2017

RQ2: How the absorption of labour, poverty and education level simultaneously to the regional minimum wage of regencies \&districts in Riau Province 2007-2017.

\section{LITERATURE REVIEW}

The Theory of Labour Demand and Supply

Definition of Labour

Labour is everyone who works in a company or business that is an integral part of the production process (BPS).In law number 13 of 2003 on Labour, the definition of labour is everyone who performs work to produce bargains and services in the fulfilment of personal or community needs as the driving force of a country's economy.

The skills and education of labour are distinguished intocoarse, skilled and educated labour. Coarse labour is labour with low education and has no skills in a field of work. Skilled labour is middle-educated labour of experience and training. While educated labour is labour with high education accompanied by expertise in a particular field.

\section{Labour Demand}

Labour demand is the number of labour required by a company at a certain level of wages. Entrepreneurs employ individuals intending to help the production of goods or services to be sold and distributed to the public. 
The increasing demand for labour is dependent on the increasing demand for the goods produced. They are part of the labour involved and trying to engage in the production of goods and services (Mulyadi, 2006).

According to Sumarsono (2009: 12-13), labour demand is influenced by several factors namely:
1)
Wage rate change

Wage rate changes will affect the company's high production costs. When used in the assumption that the rate of wages increases then there will be things like the following: (a) Increased wage levels will increase the cost of production of the company, thereby increasing the price of goods or production units produced. Consumers will respond quickly if there is a rise in the price of goods ie by reducing consumption or not buying the goods concerned. As a result, many unsold goods and manufacturers will reduce their production. The decline in production targets will result in reduced labour needed. The decrease in labour utilization will affect the scale of production, this event is called the scale effect product. (b) When wages rise it will increase the use of capitalintensive technology for the production process and replace the needs of labour with the needs of capital goods such as machinery and others. The decline in the number of labour needed due to the replacement or addition of machine use is called a substitution effect.

\section{2) \\ Market Demand to Production Results}

If the demand for the company's production increases, producers tend to increase their production capacity thus producers will increase the use of their labour force.

3)

Capital Goods Prices

If the price of capital goods falls, the production cost is down and it will result in the selling price per unit of goods will decrease. In this case, producers tend to increase their production because demand also increases. Labour demand will increase due to increased production activity.

While Budiarty (2006) states that labour demand by the company is influenced by several factors namely:
(1)
Wage rates

Wage rates from entrepreneur perspective are the cost of production, the more labour used will increase the proportion of labour cost to total cost. The increase in wages will reduce the demand for workers, while wage reductions will increase labour demand.

Technology

Utilization of technology can determine the amount of labour utilization, the more effective use of technology then the greater the opportunity of the workers to apply under their skills and abilities. Productivity

Productivity depends on the capital used if the higher it will also be high flexibility to increase productivity.

The production process can be done by utilizing a combination of capital, labour, natural resources and technology. The role of capital becomes substitutive towards workers who ultimately become a decisive factor for workers.

(5)

Labour quality

It can be measured from the level of education and experience it has. The higher the education and the work experience will improve the quality of the other labour. Other variables that can affect the quality of the labour are the nutrition and health of workers.

\section{Labour Supply}

Labour supply is the amount of labour provided by the owner of the labour on every possible wage for a specified period. Labour supply is influenced by labour decision to work or not, also influenced by Labour behaviour to use the time to be used for productive or consumptive activities. When associated with wages it will affect the high-income workers. When labour wages are higher, then the worker will reduce the time to work. This theory is based on consumer theory where every worker works to maximize satisfaction with the constraints faced (Sholeh, 2007).Factors affecting labour supply are: 1)

The larger the population, the more work that requires Labour.
2)
Population Age Structure

Although the increase in population can be suppressed the supply of labour is getting higher due to the increasing number of people entering the working age, the labour supply also increases.

3)

Education

Education is an important aspect that workers have to get into the company. The higher the level of education being completed will be the higher the labour supply required to enter the job market. 4) Level of Wages

Wage rates will affect the amount of work offer. If the wage rate rises, the total supply of labour will also increase. 


\section{Labour absorption.}

Labour absorption is the amount or quantity deferred by a business or enterprise provider. The absorbed people are scattered in various sectors that are employed in producing large scale goods and services. The ability of the business sector in absorbing labour is influenced by the growth rate of each sector and the change in labour absorption sector, in the long run, contributes to national income.

Job absorption is influenced by external and internal factors. External factors include economic growth, inflation, interest rates and unemployment. While internal factors are caused by the level of wages, labour productivity, capital and non-wage labour costs. The use of labour can be realized if there is a demand for labour in the labour market, this is part of the job opportunity. The magnitude of labour absorption is influenced by the level of the economy of a country. It is accompanied by a growth in the number of industries that can affect the amount of labour absorption. This shows the inconsistency between industrial growth and labour absorption.

\section{Wage theories}

Wages are elements that determine the underlying cost of the company. Because uncertainty in determining the number of wages will affect the sustainability of the company. Wages are an interaction between demand and supply. In the explanation of Government Regulation No. 78 the year 2015, chapter 1 article 1, wages are the right of workers /labour received and expressed in money in return for employers or employers to the workers /labour specified and paid in accordance with a work agreement, or statutory regulations, including benefits to workers in their family of a work and/or services that have been or, will be done.

According to Adam Smith in Purnami (2015) states that an increase in the average wage rate will be followed by a decrease in the number of labours sought so unemployment. On the other hand, if the wages fall then it will be followed by an increase in the amount of labor. This theory explains the existence of working hours and experience with wages. Workers tend to increase working hours to increase income, but if wages are high then labour will reduce their time to work.Smith (2003) states that the higher the output produced then the cost incurred will decrease. For example, the more ages in production the ability to produce also decreases. Costs needed to repair damaged products will be reduced.

\section{Minimum wage setting mechanism}

The government establishes a policy that regulates the mechanisms for determining the wage-based labour to meet a decent income for the workers and assures the survival of the company.Minimum Wage Assessment is a basic wage, including fixed allowance. Minimum wage is only applicable to workers who have less than one year of work. The minimum wage setting is done at the provincial level or at the district level where the Governor determines the amount of the Provincial Minimum Wage or District / Municipal Minimum Wage (UMK). Based on the proposal from the Commission on Wages and Social Security of the Regional Labour Council (Provincial Welfare Council / District).Determination is intended for safety net wages received by workers /labourers not falling below the minimum living requirement. As a result of the supply of labour that far exceeds labour demand in the job market. In addition to the minimum wage, the Governor also sets the Minimum Wage of the Sectoral Province based on a wage agreement between the company's organization and the union / laborer as that the minimum wage comprises the Provincial Minimum Wage, the Provincial Sectoral Minimum Wage and the Minimum Wage of the Regency, the Minimum Wage Sectoral.

\section{Relationship between Labor Absorption and Regional Minimum Wages.}

Wage rate changes will affect the company's high and low production costs. Increased wage levels will increase the production of the company and it will result in the company increasing the cost per unit of production items. With the increase in the cost of manufactured goods will result in consumers reducing the level of consumption, they do not even buy the item because the price offered has risen. Due to the unsold production of producers despite reducing production and resulting in the reduced number of labour needed. The quantity of requested labour will decrease as a result of the wage increase. If the rate of wages increases while inputs of other goods are fixed it means labour price is more expensive than other inputs. With the increase in labour price, the company will reduce the use of relatively expensive labour with other inputs that are relatively cheap to maintain maximum profitability.

\section{Poverty}

\section{Definition of Poverty}

Poverty is a phenomenon in human living, that is because the well-being of the family/individual is low, therefore the problem becomes complicated and needs commitment in its recovery. For the realization of a society capable of meeting the basic needs of their lives. 
Michael P Todaro points out that absolute poverty is many people who can not afford enough resources to meet basic needs, those in this position are people who have a certain minimum rill income below the international poverty line.

The Central Bureau of Statistics defines poverty as a concept of capability in fulfilling the minimum basic requirements according to the nominal quantities issued from the per capita income receivedSMERU (2001) defines poverty as a condition where a person loses his self-esteem, falls into a dependence, is forced to receive insult and cruel treatment, disregarding the need for protection.According to Sagjoyo poverty is based on the amount of household expenditure that is included with the amount of kilogram of rice consumed each year divided into rural and urban areas.

\section{Factors that cause poverty}

Mudrajad (2006) raises the cause of microcredit due to the inequality of resource ownership patterns that lead to disproportionate income distribution. Poor people only have limited resources and quality are also limited. According to Naskun, some sources and processes cause poverty: a.

Policy Induces Processes, which are preserved and deliberately produced through the implementation of policies such as policies and programs for poverty eradication but the fact is increasingly increasing poverty rates.

b.

Socio-Economic Dualism, the former colony of poverty-stricken countries, this farmer's degradation became marginalized due to the fertile soil dominated by the middlemen and large investors. c.

Population Growth, this theory is emphasized by Malthus's theory that measures poverty in line with the increase in population (measure series) and food increases are a series of calculations.

d.

Resources management and the environment, the management of natural resources and the environment that lead to poverty, for example, excessive deforestation reduces water resources and leads to crop failure.

e.

Natural Cycle and Processes, poverty caused by natural cycles, critical land conditions. When rain will occur floods and droughts will be short of the amount of water with this condition productivity will be disturbed.

f.

The marginalisation of women, poverty by making the role of women as a class, so that access and appreciation of work results are lower.

g. Cultural and Ethnic Factors, poverty caused by cultural and ethnic factors that require consumptive. Like farmers and fishermen during harvest, they perform large ceremonial and religious ceremonies.

h.

landed sharks that feel helpless when helped. i.

Exploitative Intermediation, poverty due to the bonds of

Internal Political Fragmentation and Civil Stratfe, poverty resulting from policy applied to a strong area of political fragmentation. Like political service and political revenge over an area.

j.

and capitalism

International Process, poverty is caused by colonialism

Sharp, et al (1996) view that economic poverty is due to (1) poverty is caused by inequality on the limited resources and low quality of resources. (2) poverty is caused by the low quality of human resources resulting in wages being received to be low in the cause of low education status and the existence of collusion or social discrimination in the work environment. (3) This is called the theory of the devil circle of scans found by Regnar Nurkse (1953) mentions a poor country is poor because It s poor, Persolan is caused by market imperfections and lack of capital in productivity. The low productivity is in line with the low wages the workers receive. Low wages received the ability to save and invest low. The low investment is caused by the backdrop of various sectors. Therefore, it is necessary to cut off the chain or circle of Satan's poverty.

\section{Relationship between Poverty and Regional Minimum Wages}

The primary goal of setting a minimum wage is to meet minimum living standards such as health, education, a decent and prosperous place. The minimum is a series of efforts to raise the level of poor workers. The higher the level of minimum wage received will be in line with the welfare improvement, and workers are free from poverty.

In note of Abdiyanto (2016), poverty is associated with estimates of income levels and needs. The estimate of needs is limited to the basic needs or minimum basic requirements that enable a person to live appropriately. If income levels can not meet the minimum requirements, or the family can be said to be poor. That means it takes 
a minimum level of income to enable people or families to get their basic needs. Poverty is a process where poverty reflects the failure of a community system in allocating resources and funds fairly to members of the community. Household income can be easily calculated by income and expenditure by households.

The income of the community is relatively more easily studied if it is through the expenditure side. Why is that happening, because the perpetrators of household tend to be suspicious if they ask for data about income earned for each month? From the expenditure side, it can be seen that income is found from consumption consumed by households each month. Some expenses spent fulfilling daily needs. While income is the result of all family members received from various types of activities both agriculture and non-agriculture. Then from total revenue divided by the number of family members who will earn that income. Furthermore, household income is a means to meet the needs and wants of households, the higher the level of income and the higher the welfare. Here income with well-being has a close relationship, thus income is a barrier between poor and not poor.

\section{Level of education}

\section{The nature of education}

Education is the purpose of the establishment of the Indonesian nation is to educate the nation's life. In the context of national development becomes a unity of the nation, the opportunity and potential development. According to Aulia (2008), Education Level is an instrument of hope in strengthening the integrity of the nation and providing opportunities for citizens to participate in the development and development of potential optimally.

Educational issues are closely related to job performance because of low education. Higher education is linked to becoming educators in providing teaching materials and teaching skills for the provision of education that produces quality education.

Education demands globalization era to generate competitive learners in the world of work, and have the knowledge and ability in applying them. Quality nuances in education, resulting in the working capacity of the working school. Formal education is a technical requirement to get work rate. The higher the salary is parallel with the improvement of the quality of workers.

Improved quality of human resources with higher education and wage levels is expected to reduce unemployment with formal Labour (Cateris Paribus). Many graduates describing the availability of educators is also high and good. With this situation, the level of labour force participation is also high.

\section{Education and Quality Improvement of Human Resources}

Enhance Human Resources as an effort to improve human quality with education and training development. Humans include investment in human resources or Human Capital (capital theory). Education investment is an activity that assesses human availability after education, to increase individual wages, productivity and rational value (social benefits) than before through education.

\section{Educational Pathway}

In-Law No. 20 of 2003 on the national education system in article 1, paragraph 10-13, consists ofa)Formal education is a structured and tiered educational path starting from primary, secondary, upper and tertiary education.b) Non-formal education is a formal and structured education path.c) Informal education is a family and environmental education path. The three educational pathways are interconnected in shaping personality, knowledge and skills.

\section{Relationship between Education Levels and Regional Minimum Wages.}

Education level pattern is considered to determine the minimum wage that will be accepted by the labour. Education is the process of increasing knowledge, skills, empowerment and independence to improve one's quality. It is close to the labour force in capitalizing on the company's productivity. The higher the ability to have, the greater the wages to be gained.

The ability or ability of education to be standardized in determining wages. Education as preparation of labour as a mentor of learners has basic capital for work. The basic development includes the formation of the attitude, knowledge and skills of labour workers.

The University produces a production factor called science used in the production function sectors of the manufacturing company. And the production function of university research, when universities, Labour and industry companies are mutually beneficial.The education labour until the university will have the capability to develop products and utilize science as an output increase. That will impact on the absorption of labour. The high level of education is the result of the company will encourage the company to increase the labour.

\section{Hypotheses Development}

The hypotheses of this study are as follows: 
H1: It is expected that there is a regional minimum wage effect on labourabsorption in Regencies and Districts in Riau Province.

$\mathrm{H} 2$ : It is expected that there is a regional minimum wage effect on poverty in the Regencies and Districts in Riau Province.

H3: It is expected that there is a regional minimum wage effect on the level of education in the Regencies and Districts in Riau Province.

H4: It is predicted thatLabor Absorption, Poverty and Education Levels are simultaneously affecting the application of regional minimum wages in the Regencies and Districts in Riau Province.

\section{RESEARCH METHODS}

This type of research is comparative research, including quantitative research type with the non-experimental method. Comparative research often used to determine whether there is a difference between two or more groups in the variable aspect to be investigated. Comparative research is believed to provide reliable results for testing biased instruments. This research analyzes the influence of labour absorption, poverty and education level to the regional minimum wage of regencies and districts in Riau Province. In this study it is important to plan to anticipate the incident beyond the estimates of researchers who have an impact on the results of this research and useful for readers, researchers themselves and the use of further research. The dependent variable is the regional minimum wage. Independent variables are labour absorption, poverty and education level are carried out in Riau Province that is collected from 10 regencies and 2 districts. The data are sourced from the Central Statistics Agency of Riau Province, National Social Economic Survey (Susenas), National Labor Survey (Sakernas). The secondary data period used is cross-section and times series 2007-2017. The data used are regional minimum wage, labour force absorption, poverty and education level.

Data analysis is the process of research implementation after all the data needed to the variables studied are complete. The accuracy of data obtained greatly determines the accuracy of the results and conclusions. Quantitative analysis is an inferential and inductive statistical analysis using Eviews 7 statistical software to answer, draw conclusions and decide on the results of the analysis. The analysis tool uses panel data regression or pooled data which is a combination of time series and the cross-section. Panel data can substantially lower the problem of omitted-variables, models that ignore the relevant variables (Gujarati, 2003). To overcome inter-correlation between independent variables which ultimately can result in inaccurate regression estimation, panel data method is more appropriate to use Linear regression is a statistical tool used to determine the effect of one or more variables on other variables. Observation period in this research is in 2007 2017 with 12 regencies and districts in Riau Province. To choose the right model there are several tests on model estimation techniques with panel data using the Chow Test and Hausman Test. Chow test is used to test the suitability between the pooled least square model with the fixed-effect method. For the Hausman test, it is used to test the best model obtained from a chow test with a model obtained from a random effect method.

\section{RESULTS \& DISCUSSION}

\section{Results}

Estimated Data Panel Method

Pooled Least Square

Test results by this method by combining times series and cross-section data.

Figure 1

\begin{tabular}{|c|c|c|c|c|}
\hline \multicolumn{5}{|c|}{ Dependent Variable: YT } \\
\hline \multicolumn{5}{|c|}{ Method: Panel Least Squares } \\
\hline \multicolumn{5}{|c|}{ Date: $06 / 20 / 19$ Time: $15: 44$} \\
\hline \multicolumn{5}{|c|}{ Sample: 20072017} \\
\hline \multicolumn{5}{|c|}{ Periods included: 11} \\
\hline \multicolumn{5}{|c|}{ Cross-sections included: 12} \\
\hline \multicolumn{5}{|c|}{ Total panel (balanced) observations: 132} \\
\hline Variable & Coefficient & Std. Error & t-Statistic & Prob. \\
\hline $\mathrm{C}$ & 1570376. & 152998.9 & 10.26397 & 0.0000 \\
\hline $\mathrm{X} 1 \mathrm{~T}$ & -4.575388 & 0.931265 & -4.913092 & 0.0000 \\
\hline $\mathrm{X} 2 \mathrm{~T}$ & 0.462684 & 0.265040 & 1.745715 & 0.0833 \\
\hline X3T & 2.124100 & 1.722967 & 1.232815 & 0.2199 \\
\hline
\end{tabular}


How is the effect of labour absorption, poverty and education level on the implementation of ....

\begin{tabular}{|l|c|l|l|}
\hline R-squared & 0.234266 & Mean dependent var & 1464603. \\
\hline Adjusted R-squared & 0.216319 & S.D. dependent var & 547909.6 \\
\hline S.E. of regression & 485041.2 & Akaike info criterion & 29.05169 \\
\hline Sum squared resid & $3.01 \mathrm{E}+13$ & Schwarz criterion & 29.13905 \\
\hline Log-likelihood & -1913.412 & Hannan-Quinn criter. & 29.08719 \\
\hline F-statistic & 13.05327 & Durbin-Watson stat & 0.342287 \\
\hline Prob(F-statistic) & 0.000000 & & \\
\hline
\end{tabular}

The test results of the cross-section and times series data are as follows, known that R-squared, F-statistic 13.05327 and Prob (F-statistic) 0.000000. With F significance at a $=5 \%$, that is the modelled decision of pooled least square.

\section{Fixed Effect}

This test is performed with no weighting of least square dummy variables and general least square weighting.

Figure 2

\begin{tabular}{|c|c|c|c|c|}
\hline \multicolumn{5}{|c|}{ Dependent Variable: YT } \\
\hline \multicolumn{5}{|c|}{ Method: Panel Least Squares } \\
\hline \multicolumn{5}{|c|}{ Date: $06 / 20 / 19$ Time: $15: 57$} \\
\hline \multicolumn{5}{|c|}{ Sample: 20072017} \\
\hline \multicolumn{5}{|c|}{ Periods included: 11} \\
\hline \multicolumn{5}{|c|}{ Cross-sections included: 12} \\
\hline \multicolumn{5}{|c|}{ Total panel (balanced) observations: 132} \\
\hline Variable & Coefficient & Std. Error & $\mathrm{t}$-Statistic & Prob. \\
\hline $\mathrm{C}$ & 1307505 & 225350.3 & 5.802101 & 0.0000 \\
\hline $\mathrm{X} 1 \mathrm{~T}$ & -5.532631 & 1.099802 & -5.030569 & 0.0000 \\
\hline $\mathrm{X} 2 \mathrm{~T}$ & 1.364521 & 0.427837 & 3.189348 & 0.0018 \\
\hline \multirow[t]{2}{*}{$\mathrm{X} 3 \mathrm{~T}$} & 1.898900 & 1.951641 & 0.972976 & 0.3326 \\
\hline & Effects Sp & ication & & \\
\hline \multicolumn{5}{|c|}{ Cross-section fixed (dummy variables) } \\
\hline R-squared & 0.361173 & \multicolumn{2}{|c|}{ Mean dependent var } & 1464603. \\
\hline Adjusted R-squared & 0.284733 & \multicolumn{2}{|c|}{ S.D. dependent var } & 547909.6 \\
\hline S.E. of regression & 463386.2 & \multicolumn{2}{|c|}{ Akaike info criterion } & 29.03715 \\
\hline Sum squared resid & $2.51 \mathrm{E}+13$ & \multicolumn{2}{|c|}{ Schwarz criterion } & 29.36475 \\
\hline Log-likelihood & -1901.452 & \multicolumn{2}{|c|}{ Hannan-Quinn criter. } & 29.17027 \\
\hline F-statistic & 4.724876 & \multicolumn{2}{|c|}{ Durbin-Watson stat } & 0.562142 \\
\hline Prob(F-statistic) & 0.000001 & & & \\
\hline
\end{tabular}

The approximate test results show that cross-sections are R-square 0.361173, F-statistic 4.724876 and Prob (F-statistic) 0.000001 with significance at a $=5 \%$. Thus the outcome of decision making by using fixed effect.

\section{Random Effect}

Models that include dummy that carry the consequences reduce the degree of freedom thus reducing the efficiency of the parameters. 
Figure3

\begin{tabular}{|c|c|c|c|c|}
\hline \multicolumn{3}{|c|}{ Dependent Variable: YT } & & \\
\hline \multicolumn{5}{|c|}{ Method: Panel EGLS (Cross-section random effects) } \\
\hline \multicolumn{3}{|c|}{ Date: 06/20/19 Time: $15: 59$} & & \\
\hline \multicolumn{3}{|c|}{ Sample: 20072017} & & \\
\hline \multicolumn{3}{|l|}{ Periods included: 11} & & \\
\hline \multicolumn{3}{|c|}{ Cross-sections included: 12} & & \\
\hline \multicolumn{4}{|c|}{ Total panel (balanced) observations: 132} & \\
\hline \multicolumn{5}{|c|}{ Swamy and Arora estimator of component variances } \\
\hline Variable & $\begin{array}{r}\text { Coefficien } \\
t\end{array}$ & Std. Error & t-Statistic & Prob. \\
\hline $\mathrm{C}$ & 1570376. & 146168.1 & 10.74363 & 0.0000 \\
\hline $\mathrm{X} 1 \mathrm{~T}$ & -4.575388 & 0.889688 & -5.142690 & 0.0000 \\
\hline $\mathrm{X} 2 \mathrm{~T}$ & 0.462684 & 0.253207 & 1.827295 & 0.0700 \\
\hline \multirow[t]{3}{*}{$\mathrm{X} 3 \mathrm{~T}$} & 2.124100 & 1.646044 & 1.290427 & 0.1992 \\
\hline & \multicolumn{2}{|c|}{ Effects Specification } & & \\
\hline & & & S.D. & Rho \\
\hline \multicolumn{3}{|l|}{ Cross-section random } & 0.000000 & 0.0000 \\
\hline \multicolumn{3}{|l|}{ Idiosyncratic random } & 463386.2 & 1.0000 \\
\hline & \multicolumn{2}{|c|}{ Weighted Statistics } & & \\
\hline R-squared & 0.234266 & \multicolumn{2}{|c|}{ Mean dependent var } & 1464603. \\
\hline Adjusted R-squared & 0.216319 & \multicolumn{2}{|c|}{ S.D. dependent var } & 547909.6 \\
\hline S.E. of regression & 485041.2 & \multicolumn{2}{|c|}{ Sum squared resid } & $3.01 \mathrm{E}+1$ \\
\hline F-statistic & 13.05327 & \multicolumn{2}{|c|}{ Durbin-Watson stat } & 0.342287 \\
\hline \multirow[t]{2}{*}{ Prob(F-statistic) } & 0.000000 & & & \\
\hline & \multicolumn{2}{|c|}{ Unweighted Statistics } & & \\
\hline R-squared & 0.234266 & \multicolumn{2}{|c|}{ Mean dependent var } & 1464603. \\
\hline Sum squared resid & $3.01 \mathrm{E}+13$ & \multicolumn{2}{|c|}{ Durbin-Watson stat } & 0.342287 \\
\hline
\end{tabular}

The result of the test found that the result of R-square 0.234226, F-statistic 13.05327 and Prob (F-statistic) 0.000000 with $\mathrm{F}$ significance $\mathrm{a}=5 \%$, then in the result of the decision of random effect.

Testing Data Panel Methods with Chi-Square Testing.

This method is used to compare whether the model is a fixed effect by comparing the F-statistic of Ftable.

Figure.4

\begin{tabular}{|c|c|c|c|c|}
\hline \multicolumn{5}{|c|}{ Redundant Fixed Effects Tests } \\
\hline \multicolumn{5}{|c|}{ Equation: COMMON } \\
\hline \multicolumn{5}{|c|}{ Test cross-section fixed effects } \\
\hline \multicolumn{2}{|c|}{ Effects Test } & Statistic & d.f. & Prob. \\
\hline \multicolumn{2}{|c|}{ Cross-section F } & 2.112992 & $(11,117)$ & 0.0244 \\
\hline \multicolumn{2}{|c|}{ Cross-section Chi-square } & 23.918670 & 11 & 0.0131 \\
\hline \multicolumn{5}{|c|}{ Cross-section fixed effects test equation: } \\
\hline \multicolumn{5}{|c|}{ Dependent Variable: YT } \\
\hline \multicolumn{5}{|c|}{ Method: Panel Least Squares } \\
\hline \multicolumn{5}{|c|}{ Date: 06/20/19 Time: $16: 02$} \\
\hline \multicolumn{5}{|c|}{ Sample: 20072017} \\
\hline \multicolumn{5}{|c|}{ Periods included: 11} \\
\hline \multicolumn{5}{|c|}{ Cross-sections included: 12} \\
\hline \multicolumn{5}{|c|}{ Total panel (balanced) observations: 132} \\
\hline Variable & Coefficient & Std. Error & t-Statistic & Prob. \\
\hline $\mathrm{C}$ & 1570376. & 152998.9 & 10.26397 & 0.0000 \\
\hline
\end{tabular}


How is the effect of labour absorption, poverty and education level on the implementation of ....

\begin{tabular}{|l|r|r|r|r|}
\hline \multicolumn{1}{|c|}{ X1T } & -4.575388 & 0.931265 & -4.913092 & 0.0000 \\
\hline \multicolumn{1}{|c|}{ X2T } & 0.462684 & 0.265040 & 1.745715 & 0.0833 \\
\hline \multicolumn{1}{|c|}{ X3T } & 2.124100 & 1.722967 & 1.232815 & 0.2199 \\
\hline R-squared & 0.234266 & \multicolumn{2}{|c|}{ Mean dependent var } & 1464603. \\
\hline Adjusted R-squared & 0.216319 & \multicolumn{2}{l|}{ S.D. dependent var } & 547909.6 \\
\hline S.E. of regression & 485041.2 & Akaike info criterion & 29.05169 \\
\hline Sum squared resid & $3.01 E+13$ & \multicolumn{2}{l|}{ Schwarz criterion } & 29.13905 \\
\hline Log-likelihood & -1913.412 & Hannan-Quinn criter. & 29.08719 \\
\hline F-statistic & 13.05327 & Durbin-Watson stat & 0.342287 \\
\hline Prob(F-statistic) & 0.000000 & \multicolumn{2}{|l}{} \\
\hline
\end{tabular}

Based on the chow test results on the attachment, it is known that the output, if the probability chi-square $<0.05$, then the chosen is the fixed effect. Whereas if probability $>0.05$, then the chosen is common / pooled effect. Probability chi-square shows the figure of 0.01 , where smaller than 0.05 , it is concluded that the model chosen is the Fixed Effect Model.

\section{Testing Data Panel Methods with Hausman Testing}

This test is used to view and select the fixed effect model or the appropriate random effect.

Figure 5

\begin{tabular}{|c|c|c|c|c|}
\hline \multicolumn{4}{|c|}{ Correlated Random Effects - Hausman Test } & \\
\hline \multirow{2}{*}{\multicolumn{4}{|c|}{$\begin{array}{l}\text { Equation: COMMON } \\
\text { Test cross-section random effects }\end{array}$}} & \\
\hline & & & & \\
\hline \multicolumn{2}{|c|}{ Test Summary } & $\begin{array}{l}\text { Chi-Sq. } \\
\text { Statistic }\end{array}$ & Chi-Sq. d.f. & Prob. \\
\hline \multicolumn{2}{|c|}{ Cross-section random } & 21.407153 & 3 & 0.0001 \\
\hline \multicolumn{5}{|c|}{ ** WARNING: estimated cross-section random effects variance is zero. } \\
\hline \multicolumn{5}{|c|}{ Cross-section random effects test comparisons: } \\
\hline Variable & Fixed & Random & Var(Diff.) & Prob. \\
\hline $\mathrm{X} 1 \mathrm{~T}$ & -5.532631 & -4.575388 & 0.418021 & 0.1387 \\
\hline $\mathrm{X} 2 \mathrm{~T}$ & 1.364521 & 0.462684 & 0.118931 & 0.0089 \\
\hline $\mathrm{X} 3 \mathrm{~T}$ & 1.898900 & 2.124100 & 1.099439 & 0.8299 \\
\hline \multicolumn{4}{|c|}{ Cross-section random effects test equation: } & \\
\hline \multicolumn{4}{|c|}{ Dependent Variable: YT } & \\
\hline \multicolumn{5}{|c|}{ Method: Panel Least Squares } \\
\hline \multicolumn{5}{|c|}{ Date: 06/20/19 Time: $16: 09$} \\
\hline \multicolumn{5}{|c|}{ Sample: 20072017} \\
\hline \multicolumn{5}{|c|}{ Periods included: 11} \\
\hline \multicolumn{5}{|c|}{ Cross-sections included: 12} \\
\hline \multicolumn{5}{|c|}{ Total panel (balanced) observations: 132} \\
\hline Variable & Coefficient & Std. Error & t-Statistic & Prob. \\
\hline $\mathrm{C}$ & 1307505. & 225350.3 & 5.802101 & 0.0000 \\
\hline $\mathrm{X} 1 \mathrm{~T}$ & -5.532631 & 1.099802 & -5.030569 & 0.0000 \\
\hline $\mathrm{X} 2 \mathrm{~T}$ & 1.364521 & 0.427837 & 3.189348 & 0.0018 \\
\hline \multirow[t]{2}{*}{$\mathrm{X} 3 \mathrm{~T}$} & 1.898900 & 1.951641 & 0.972976 & 0.3326 \\
\hline & Effects Spe & cation & & \\
\hline \multicolumn{5}{|c|}{ Cross-section fixed (dummy variables) } \\
\hline R-squared & 0.361173 & \multicolumn{2}{|c|}{ Mean dependent var } & 1464603. \\
\hline Adjusted R-squared & 0.284733 & \multicolumn{2}{|c|}{ S.D. dependent var } & 547909.6 \\
\hline S.E. of regression & 463386.2 & \multicolumn{2}{|c|}{ Akaike info criterion } & 29.03715 \\
\hline Sum squared resid & $2.51 \mathrm{E}+13$ & \multicolumn{2}{|c|}{ Schwarz criterion } & 29.36475 \\
\hline Log-likelihood & -1901.452 & \multicolumn{2}{|c|}{ Hannan-Quinn criter. } & 29.17027 \\
\hline F-statistic & 4.724876 & \multicolumn{2}{|c|}{ Durbin-Watson stat } & 0.562142 \\
\hline Prob(F-statistic) & 0.000001 & & & \\
\hline
\end{tabular}


Based on the test results from the Hausman test above, if probability $>0.05$ then selected random effect. If the probability $<0.05$ then selected is a fixed effect. From the result of the Hausman test calculation, the probability value is 0.0001 which is smaller than 0.05 so the model chosen is the Fixed Effect Model.

\section{Statistical Test Estimation}

The model used after the transformation of dependent and independent variables is as follows: In $(\mathrm{X} 1 \mathrm{~T})=\mathrm{Bo}+\mathrm{B} 1 \mathrm{In}(\mathrm{X} 1 \mathrm{~T})+\mathrm{B} 2 \mathrm{In}(\mathrm{X} 2 \mathrm{~T})+\mathrm{B} 3 \mathrm{In}(\mathrm{X} 3 \mathrm{~T})$

Figure 6

\begin{tabular}{|c|c|c|c|c|}
\hline \multicolumn{3}{|c|}{ Dependent Variable: LOGYT } & & \\
\hline \multicolumn{4}{|c|}{ Method: Panel EGLS (Cross-section weights) } & \\
\hline \multicolumn{3}{|c|}{ Date: 06/20/19 Time: $23: 56$} & & \\
\hline \multicolumn{3}{|c|}{ Sample: 20072017} & & \\
\hline \multicolumn{3}{|l|}{ Periods included: 11} & & \\
\hline \multicolumn{3}{|c|}{ Cross-sections included: 12} & & \\
\hline \multicolumn{4}{|c|}{ Total panel (balanced) observations: 132} & \\
\hline \multicolumn{5}{|c|}{ Linear estimation after one-step weighting matrix } \\
\hline Variable & Coefficient & Std. Error & t-Statistic & Prob. \\
\hline $\mathrm{C}$ & 11.02970 & 1.444572 & 7.635275 & 0.0000 \\
\hline LOGX1T & -0.334756 & 0.055209 & -6.063418 & 0.0000 \\
\hline LOGX2T & 0.448582 & 0.086273 & 5.199547 & 0.0000 \\
\hline \multirow[t]{2}{*}{ LOGX3T } & 0.105772 & 0.039126 & 2.703399 & 0.0079 \\
\hline & Effects S & ification & & \\
\hline \multicolumn{5}{|c|}{ Cross-section fixed (dummy variables) } \\
\hline & \multicolumn{2}{|c|}{ Weighted Statistics } & & \\
\hline R-squared & 0.568776 & \multicolumn{2}{|c|}{ Mean dependent var } & 15.59316 \\
\hline Adjusted R-squared & 0.517177 & \multicolumn{2}{|c|}{ S.D. dependent var } & 3.988329 \\
\hline S.E. of regression & 0.297936 & \multicolumn{2}{|c|}{ Sum squared resid } & 10.38563 \\
\hline F-statistic & 11.02291 & \multicolumn{2}{|c|}{ Durbin-Watson stat } & 0.775071 \\
\hline $\operatorname{Prob}($ F-statistic) & 0.000000 & & & \\
\hline
\end{tabular}

\section{T-test}

The t-test was conducted to find out whether the free variables in this study were the level of labour absorption, poverty and education level significantly affecting the dependent variable ie the regional minimum wage of regencies and districts. This test is done by looking at each value of the t-statistic probability of each independent variable. If the probability value $>\mathrm{a}=0,05$ then Ho is accepted. If the probability value $<\mathrm{a}=0,05$, then $\mathrm{H} 1$ is accepted.The result of t-test performed if the probability value $<0,05$ then the variable $\mathrm{X} /$ independently has a significant influence on $\mathrm{Y} /$ dependent. It appears that the probability values of X1T $(0,0000), \mathrm{X} 2 \mathrm{~T}(0.000), \mathrm{X} 3 \mathrm{~T}(0.0079)$ are significant to Y.

\section{F-test}

This test is done simultaneously as well as overall of regression coefficients of independent variables to dependent variables. F test is done by looking at the probability of F-statistic. If its value $>\mathrm{a}=0,05$ then Ho is rejected. If the probability value of F-statistic $<\mathrm{a}=0,05$ then $\mathrm{H} 1$ is accepted. From the $\mathrm{F}$ test result of Probability F-statistic <a $=0,05$ then H1, accepted. Thus the result shows a regression model that is feasible to calculate the influence of labour absorption, poverty and education level to the regional minimum wage of regencies and districts in Riau province. Or an explanation of the effect of the three independent variables on dependent variables.

\section{R2-Determination Coefficiency Test}

This test is used to determine the magnitude of the influence of independent variables on the dependent variable. From the R-Square result in the image above with the value 0,568776 indicates that the proportion of the $\log$ variable $(\mathrm{X} 1 \mathrm{~T}), \log (\mathrm{X} 2 \mathrm{~T}), \log (\mathrm{X} 3 \mathrm{~T})$ is $56.87 \%$. It means the influence of labour absorption, poverty 
and education level as a proportion of the impact on the regional minimum wage of the regencies and districts in Riau Province by $56.87 \%$. The rest is influenced by other variables that do not exist in the regression model.

\section{Economic Analysis}

\section{DISCUSSION}

Based on the result of statistical calculations, it can be concluded that the regression result is used to explain the influence of labour, poverty and education level on the regional minimum wage of regencies and districts in Riau Province.

Here is the Estimation Equation of dependent and independent variables:

Estimation Equation:

$\mathrm{LOGYT}=\mathrm{C}(1)+\mathrm{C}(2) * \mathrm{LOGX} 1 \mathrm{~T}+\mathrm{C}(3) * \mathrm{LOGX} 2 \mathrm{~T}+\mathrm{C}(4) * \mathrm{LOGX} 3 \mathrm{~T}+[\mathrm{CX}=\mathrm{F}]$

Substituted Coefficients:

$\operatorname{Ln}(\mathrm{YT})=11.0297045538-0.334756190233 \ln (\mathrm{X} 1 \mathrm{~T})+0.448582156522 \ln (\mathrm{X} 2 \mathrm{~T})+0.10577226882 \ln (\mathrm{X} 3 \mathrm{~T})+$ $[\mathrm{CX}=\mathrm{F}]$

The regression coefficient of In (X1T) $(-0,334)$ is negative, meaning that in the event of an increase in labour absorption, the regional minimum wage set by the regencies and districts government will decrease, as well as the opposite. If there is an increase in the number of labour absorption by $1 \%$ assumptions, it will reduce the regional minimum wage by $0.33 \%$, assuming that other independent variables are worth zero. Regression coefficients of In (X2T) (0.448) and In (x3T) (0.105) are both positive values. If there is an increase in the In $(\mathrm{X} 2 \mathrm{~T})$ variable namely poverty and In (X3T) that is the level of education. With minimum regional wages also increases, so on the contrary. Also, poverty is the dominant factor in the regional minimum wage because it has a large regression coefficient value compared to other variables in the regression model. If there is a regional minimum wage increase of $1 \%$ then the poverty incidence is $0.44 \%$.

\section{The effect of regional minimum wage of regencies and districts in Riau Province on labour absorption.}

Wages are safety net over the minimum standard reference of the benefits received after the production. In increasing the number of Labour opportunities for the labour how governments can control unemployment workers growth. The data used in this study is based on the regional minimum wage set by the provincial government of Riau starting from 2007-2017.From the results of findings and data processing by researchers, the effect of the minimum wage of regencies and districts in Riau Province on the absorption of labour has no influence and is negative. If there is an increase of $1 \%$ to the minimum wage then the absorption of labour occurs a decrease of labour absorption by $0.334 \%$.

In the findings found by researchers in analyzing data on labour absorption caused by wage increases, it is negatively associated. The perspective is that the researcher concludes from the labour force to the minimum wage of the regencies and districts in Riau Province is if there is a wage increase then the absorption of labour will decrease and vice versa. The change in minimum wage placed by the government caused the company to reduce capital costs.

\section{The effect of regional minimum wage of regencies and districts in Riau Province on poverty.}

Poverty is the inability of the population in allocating the opinions they have in fulfilling the requirements. With growing large number of poverty increases into an economic burden, because the number of dependent populations is huge. In terms of the development process, it also has problems because the available human resources are weakly competitive. Based on data processing and author analysis on research on the effect of minimum wages on poverty in Riau is positive. If there is a minimum wage increase of $1 \%$ with other factor assumptions of cateris paribus there is a reduction in the amount of poverty of $0.44 \%$. From the writer's findings, the rate of poverty increases in proportion to the minimum wage increase set by the government. Wages are a major factor in the rise of poverty in Riau in this research material. So with this kind of condition, the minimum wage function against poverty in the regencies and districts in Riau Province is two sides. First, the minimum wage increases lead to a reduction in poverty and secondly if minimum wages fall, poverty increases.

\section{The effect of regional minimum wage of regencies and districts in Riau Province on Education level.}

Education is one of the backbones of economic development, as the labour is high, it tends to get big wages. They are more dominant in the position of a formal job with a good standard of wages. In this study, education level data used by researchers is a population of 15 years and above who graduated from vocational 
high school to university level. From the findings, if there is an increase if there is a minimum wage increase of $1 \%$, the population at the secondary education level to the receiving university only increases by $0.105 \%$. This is the lowest count result compared to two other variable results. From the findings of the authors argue, the minimum wage set by the government is still low received by educated workers. And when there is a decline in the minimum wage, the minimum educated labour is low on wages.

\section{Conclusion}

\section{CONCLUSIONS \& SUGGESTIONS}

Based on the results of the research and discussion, some of the conclusions that can be taken are as follows:1) The results of the t-test indicate that probability variables X1T of 0.000000 and X2T of $0.000000 \mathrm{da}$ $\mathrm{X} 3 \mathrm{~T}$ of 0.0079 are significant to $\mathrm{Y}$ because $<0,05$, or labour absorption, poverty and education levels are significant application of regional minimum wage of regencies and districts in Riau Province 2007-2017. 2) The F-test result obtained F-statistical probability with the result of 0.001 indicates that the significance of F-count $<0,05$. Thus, the result is a regression made in the estimation of variables of labour absorption, poverty and education level affecting the variable of regional minimum wage of regencies and districtsin Riau Province.3) The calculation of $\mathrm{R}$ Square value of 0,568776 shows that the effect of log variable (X1T) labour absorption, log (X2T) poverty, $\log (\mathrm{X} 2 \mathrm{~T})$ education level to $\log (\mathrm{YT})$ is $56,87 \%$. With these results, there is a significant influence on the absorption of labour, poverty and education level to the application of regional minimum wage of regencies and districts in Riau Province by $56.87 \%$, the rest is influenced by other variables that do not exist in the regression model.4) The result of model interpretation, Ln (X1T) variable absorption of labour is negative $(-0,334)$. if there is an increase in labour absorption then the regional minimum wage decreases. if there is an increase of $1 \%$ of the total labour absorbed by the company then there is a reduction of the regional minimum wage of $0.33 \%$ with other variables assumed to be zero. The regression coefficient of Ln (X2T) poverty and In (X3T) education level is positive. If there is an increase of $1 \%$ of poverty and education level then the regional minimum wage of the regencies and districts will increase. The resulting poverty coefficient reaching 0.44 has the dominant aspect of the minimum wage. While the coefficient of education level only 0,105 is the lowest coefficient result of this regression model.

\section{Suggestions}

Based on the results of the research, some suggestions can be presented as follows:The t-test calculation results show a significant relationship between dependent and independent variables. Therefore it is recommended that independent variables should be included in the formulation of the regional minimum wage calculation. As a key factor in the development of economic quality in the human aspect. If labour is not absorbed by job opportunities, then they will live poorly because it is not maximized to cover the needs of life. Education as a mandatory tool in improving human quality does not go as expected as the ability to finance has never existed. They did not have a job, there was a vicious circle.It is also consistent with F-test results that the three independent variables are worth estimating in the calculation of regional minimum wages. Because the proportion of its influence was $56.87 \%$ (the result of R2 test)The results of the coefficients between minimum wages and labour absorption are negative. Here's how to pull and back companies in providing / opening job opportunities. To suppress the production price to keep the path and profit of the labour can be decided on its relationship. Or change the working capital in production into a machine. As a result, labour becomes a bit. Needs to be eliminated outsourcing/contract/ internship apprenticeship. The company must be responsible for ensuring the welfare of the labour force and the government has the role of providing Labour. With the concept of sustainability for fellow beings.Positive value coefficients of poverty and education level towards the application of regional minimum wage of regencies and districts in Riau Province. Because there is an equal pull if wages go up then the poverty and acceptance level of education also goes up, and vice versa.Riau Province as the rapidly developing administration of natural resources exploration areas is expected to reduce the number of poverty and the increase in the number of educated workers to receive a minimum wage increase as the minimum wage setting rises.

\section{REFERENCES}

[1]. Abdiyanto. 2016. Ekonomi Kemiskinan. Medan: USU Press.

[2]. Barthos Basir. 2012, “Manajemen Sumber Daya Manusia Suatu Pendekatan Makro”.Jakarta : Bumi Aksara.

[3]. Budiarty,Ia. 2006. Ekonomi Sumber Daya Manusia. Universitas Lampung. Bandar lampung.

[4]. Kuncoro, Mudajat. (2006). "Ekonomi Pembangunan Teori, Masalah dan Kebijakan Edisi Keempat”.UPP AMP YKN, Yogyakarta.

[5]. Mulyadi, Subri. 2003. Ekonomi Sumber Daya Manusia. PT Raja Grafindo Persada. Jakarta.

[6]. Payaman, Simanjuntak. 2002. Pengantar Sumber Daya Manusia. Universitas Indonesia, Jakarta. 
How is the effect of labour absorption, poverty and education level on the implementation of ....

[7]. Pracoyo, Tri kunawaningsih. 2007. “Aspek Dasar Ekonomi Makro di Indonesia”, Jakarta.

[8]. Sumarsono,Sonny. 2009. Teori dan Kebijakan Publik, Ekonomi Sumber Daya Manusia. Graha Ilmu, Yogyakarta.

[9]. Suparmoko, M dan Irawan.2002.”Ekonometrika Pembangunan”.BPFE-YOGYAKARTA.Yogyakarta.

[10]. Todaro, Michael P. 2000. “Ilmu Ekonomi Bagi Negara Sedang Berkembang”. Erlangga, Jakarta.

[11]. Todaro,M., \& Smith, S. 2006. Pembangunan Ekonomi. Edisi Keseimbangan. Erlangga. Jakarta.

[12]. Winarno, Wing Wahyu, 2009. “Analisis EKonometrika dan Statistika Dengan Eviews”. UPP STIM YKPN, Yogyakarta.

[13]. Ayu, Sekar Dita. 2018. Analisis Pengaruh Produk Domestik Regional Bruto, Tingkat Pengangguran Terbuka, IPM, Jumlah Penduduk dan Upah Minimum Terhadap Kemiskinan di Provinsi Jawa Timur (tahun 2010-2015). Skripsi. Yogyakarta. Universitas Islam Indonesia. https://dspace.uii.ac.id/bitstream/handle/123456789/9528/JURNAL\%20Dita\%20Sekar\%20Ayu.pdf?se quence=2\&isAllowed=y 4 April 2019, 9:19 AM.

[14]. Badan Pusat Statistik. 2008. "Provinsi Riau Dalam Angka 2008”. Provinsi Riau.

[15]. ----------------- 2009. “Provinsi Riau Dalam Angka 2009”. Provinsi Riau.

[16]. ------------- 2010. “Provinsi Riau Dalam Angka 2010”. Provinsi Riau.

[17]. ------------- 2011. "Provinsi Riau Dalam Angka 2011". Provinsi Riau

[18]. ------------------ 2012. “Provinsi Riau Dalam Angka 2012”. Provinsi Riau

[19]. --------------------- 2013. “Provinsi Riau Dalam Angka 2013”. Provinsi Riau

[20]. ----------------- 2014. “Provinsi Riau Dalam Angka 2014”. Provinsi Riau

[21]. --------------------- 2015. “Provinsi Riau Dalam Angka 2015”. Provinsi Riau

[22]. ------------------- 2016. "Provinsi Riau Dalam Angka 2016”. Provinsi Riau

[23]. - ---------------- 2017. “Provinsi Riau Dalam Angka 2017”. Provinsi Riau

[24]. - ---------------- 2018. “Provinsi Riau Dalam Angka 2018”. Provinsi Riau

[25]. Kristanto, Ilham. 2013. Analisis Penetapan Upah Minimum Kabupaten Jember. Skripsi. Fakultas Ekonomi. Universitas Jember. Jember.

[26]. Kiristanto, Prabowo Dwi. 2014. Analisis Pengaruh Pertumbuhan Ekonomi, Upah Minimum dan Tingkat Pengangguran Terhadap Jumlah Penduduk Miskin di Kabupaten Brebes tahun 1997-2012. 2014. Skripsi. Universitas Diponegoro.

[27]. Pedoman Penulisan Karya Ilmiah Fakultas Ekonomi Universitas Pembangunan Panca Budi, 2014. Medan.

[28]. Purnami, Izatun. 2015. Pengaruh Tingkat Pendidikan dan Upah Minimum Kabupaten/Kota terhadap penyerapan Tenaga Kerja di Provinsi Jawa Barat. Skripsi. Universitas Islam Syarif Hidayatullah. Jakarta. http://repository.uinjkt.ac.id/dspace/bitstream/123456789/30167/1/IZATUN\%20PURNAMIFEB.pdf 5 April 2019, 9:12 PM.

[29]. Sandi, Debi Ruli. 2013. "Pengaruh Tingkat Pendidikan dan PDRB Terhadap Penyerapan Tenaga Kerja pada Usaha Sektor Pertanian di KabupatenJombang”. Sekolah Tinggi Keguruan dan Ilmu Pendidikan Persatuan Guru Republik Indonesia , Jombang.

[30]. Saputra, Whisnu Adhi. 2011. Analisis Pengaruh Jumlah Penduduk, PDRB, IPM, Pegangguran Terhadap Tingkat Kemiskinan di Kabupaten/Kota Jawa Tengah. Skripsi . Universitas Diponegoro. Semarang. http://eprints.undip.ac.id/28982/1/Skripsi018.pdf 4 April 2019, 9:10 AM.

[31]. Tambunsaribu, Roms Yossia. 2013. Analisis Pengaruh Produktivitas Tenaga Kerja, Upah Rill dan Pertumbuhan Ekonomi Terhadap Penyerapan Tenaga Kerja di Jawa Tengah. Skripsi. Universitas Diponegoro. Semarang, https://core.ac.uk/download/pdf/13653495.pdf 5 Maret 2019, 9:29 PM.

[32]. Semarang. http://eprints.undip.ac.id/43469/1/03_KRISTANTO.pdf 4 April 2019, 9:24 AM

[33]. Undang-undang Republik Indonesia, nomor 13 tahun 2003 Tentang ketenagakerjaan, Jakarta.

[34]. Undang-undang Republik Indonesia nomor 20 tahun 2003 tentang Sistem Pendidikan Nasional, Jakarta.

[35]. Wardani, Listyaningrum Kusuma. 2013. Pengaruh Pengangguran, Pengeluaran Pemerintah dan Jumlah Penduduk Terhadap Kemiskinan Kab/Kota di Jwa tengah 2006-2010. Skripsi. Universitas Negeri Semarang. Semarang. https://lib.unnes.ac.id/18211/1/7450407052.pdf 4 April 2019, 9:23 AM.

[36]. Sulistiawati, Rini. 2012. Pengaruh Upah Minimum Terhadap Penyerapan Tenaga Kerja dan Kesejahteraan masyarakat di Provinsi Se-Indonesia. Jurnal Fakultas Ekonomi Universitas Tanjungpura. Volume 8, Nomor 3, Oktober 2012.

*Corresponding Author: Abdiyanto Department of Development Economic Universitas Pembangunan Panca Budi, Medan, North Sumatra, Indonesia 